\title{
A study of the food intake and activity of a group of urban adolescents
}

\author{
By JEAN W. MCNAUGHTON AND AUDREY J. CAHN \\ Russell Grimwade School of Biochemistry, University of Melbourne, \\ Parkville, Australia
}

(Received 26 August 1969-Accepted 2 October 1969)

\begin{abstract}
1. Information was obtained on the activity and food intake of ninety-two boys and 186 girls aged 16-19 years over a period of 7 days. Seventy-four boys and 132 girls were students, and eighteen boys and fifty-four girls were employed.

2. Each subject recorded daily activity on a chart divided into squares corresponding to $5 \mathrm{~min}$, using a code letter for each type of activity. The amounts of all foods and beverages consumed each day were recorded in a food diary.

3. The energy expenditure of each subject was estimated from selected values for the energy cost of each activity. The intakes of calories and nutrients were calculated from tables of food composition.

4. It was found that the subjects spent very little time in strenuous physical exertion. There were slight differences between the age-group and the occupation groups, but between 78 and $80 \%$ of the total time was spent in bed or seated, $14-20 \%$ in very light to light physical activity and only $1 \cdot 5-4.4 \%$ in any activity greater than walking at an even pace.

5. The group means for estimated energy expenditure in kcal, with their standard deviations, were: schoolboys aged I6-I 7, 2780 250 ; employed boys aged I6-I 7, 2890 240 ; schoolboys

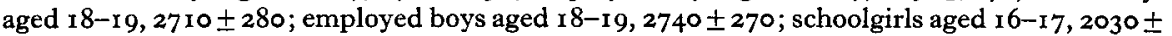
170; employed girls aged 16-17, 2140 240 ; schoolgirls aged 18-19, 2040 \pm 190; trainee teachers aged $18-19,1900 \pm 140$; employed girls aged $18-19,2070 \pm 160$.

6. Group means for the intake of kcal were: schoolboys aged 16-17,3040 540 ; employed boys aged $16-17,2730 \pm 520$; schoolboys aged 18-19, $3110 \pm 450$; employed boys aged I8-19, $2700 \pm 170 ;$ schoolgirls aged $16-17,2140 \pm 420$; employed girls aged $16-17,1910 \pm 310 ;$ schoolgirls aged I 8-19,2400 \pm 310 ; trainee teachers aged $18-19,2020 \pm 330$; employed girls aged $18-19,2030 \pm 440$

7. The employed girls aged 16-17 had lower intakes of calories and all nutrients than the schoolgirls of the same age.

8. No correlation was found between the weight and calorie intake of individual subjects, nor between their calorie intake and energy expenditure during the time interval studied. The results indicated that for these Australian subjects, calorie balance was not achieved over a period of a few days. This is in accord with evidence of workers in other countries.

9. The findings suggest the need for further studies on the nutritional status of Australian employed girls aged $16-17$.
\end{abstract}

Although investigators in several other countries (Bedale, 1922-3; Wiehl, I944; Borisov, I961; Maksimov, I96r ; Huenemann, Shapiro, Hampton \& Mitchell, 1967) have studied the activity and energy expenditure of children in relation to their calorie intakes, similar studies have not been made in Australia. Calorie allowances of Australian children have been based on the observed intakes of healthy children (National Health and Medical Research Council: Australia, I96r) those for older children being derived from data from the United Kingdom and the USA.

The present study was therefore undertaken to obtain information on the energy expenditure and food intake of young Australians aged between 16 and 19 years. The results were made available to the Nutrition Committee of the National Health and 
Medical Research Council for their revision of the dietary allowances in 1965 (National Health and Medical Research Council: Australia, 1965).

\section{EXPERIMENTAL}

\section{General procedure}

Volunteers aged between 16 and I 9 years living in Melbourne recorded their activity and their food intake over a 7 -day period. The information was obtained between June and October $196 \mathrm{I}$, i.e. in the winter and spring.

Mean maximum and minimum daily temperatures in Melbourne during these months were: June $15.16^{\circ}$ and $8.05^{\circ}$, July $13.83^{\circ}$ and $6.72^{\circ}$, August $15.50^{\circ}$ and $6.88^{\circ}$, September $19^{\circ} 00^{\circ}$ and $7.83^{\circ}$.

The volunteers were obtained from the following sources:

(1) An independent boarding and day school for girls (school I). In general the parents of the girls were well-to-do.

(2) An independent school for boys (school 2). Parents of these boys were of similar income level to the parents of the girls at school $\mathrm{r}$.

(3) A co-educational State-run secondary school (school 3). This school was selected because many families in the area it served were of lower socio-economic level than the families of the children attending schools $I$ and 2 .

(4) A teachers' training college adjacent to the University of Melbourne.

(5) A large retail store in the centre of Melbourne (store I).

(6) A city branch of a large chain of stores (store 2).

(7) A men's retail clothing store (store 3).

(8) A food processing factory (factory).

(9) A woollen mill (mill).

Difficulties were experienced in obtaining volunteers from commerce and industry, and as a result the sample contained a greater proportion of schoolchildren than the general Melbourne population aged between 16 and 19 years.

Table I. Sources of volunteers for the study

\begin{tabular}{llrr} 
& & \multicolumn{2}{c}{ No. of subjects } \\
Source of sample & Occupation & i & 77 \\
School I & Students & 42 & - \\
School 2 & Students & 32 & 40 \\
School 3 & Students & - & I5 \\
Teachers' college & Students & - & 7 \\
Store I & Sales staff & - & 19 \\
Store 2 & Office staff & - & 4 \\
& Sales staff & - & - \\
Store 3 & Office staff & 7 & 4 \\
Factory & Sales staff & - & 2 \\
Mill & Office staff & - & 1
\end{tabular}


The numbers, sex and occupation of the volunteers who completed the study satisfactorily and whose records are used in this paper are shown in Table I. Values for any subject who reported an illness during the study have been omitted.

At the beginning of the study the participants were interviewed by one of us (J. McN.) and shown the methods to be used to record activity and food intake. The records from each group were carefully checked for any inconsistencies or omissions at the end of the 7-day period and subjects were then interviewed again in order to clarify any ambiguous entries in the records.

\section{Methods}

Age, height and weight. The age, height without shoes and weight wearing indoor clothing were recorded for each subject on the ist day of the study. Weights were recorded again on the final day of the study for 245 subjects.

Activity. The method described by Garry, Passmore, Warnock \& Durnin (1955) was used. Each subject recorded his or her activity in a booklet with a page for each $24 \mathrm{~h}$ divided into squares of $5 \mathrm{~min}$. Different code letters were used to denote different activities, the appropriate code letters being placed in a square to indicate the activity during a particular $5 \mathrm{~min}$. Squares could be divided when an activity took less than 5 min to perform.

Energy expenditure. The values assigned for the energy cost of each activity after a study of the literature are shown in Table 2. No increment was added to allow for the energy cost of growth.

The basal metabolic rate was used as a measure of metabolism when the subject was sleeping or lying in bed. The surface area was obtained using a nomogram (Consolazio, Johnson \& Marek, I95I), and the BMR was then calculated from the standards of Robertson \& Reid (1952). The values used to estimate the energy cost of walking were taken from McDonald (1961), an average rate of walking of $80 \mathrm{~m} / \mathrm{min}$ (approximately 3 miles $/ \mathrm{h})$ being selected for the boys, and $70 \mathrm{~m} / \mathrm{min}(2.6 \mathrm{miles} / \mathrm{h})$ for the girls. Sedentary occupations such as reading, watching television and movies have been grouped together as 'leisure, sitting'.

Many subjects used the terms chores or housework to record activity over a specific period when in fact several different types of activity, such as gardening, dish washing, sweeping, and polishing might have been undertaken. In such instances the energy cost of manual labour was assessed at $4.5 \mathrm{kcal} / \mathrm{min}$ for the boys, since their most usual tasks were chopping and stacking wood, mowing lawns, gardening and car cleaning. A value of $3.5 \mathrm{kcal} / \mathrm{min}$ was adopted for the energy expended on household tasks by girls.

Less information was available on the energy expended during sports than for most other activities. When values for the energy cost of a particular sport were not available in the literature, a value was assigned on the basis of the degree of activity involved in the sport in comparison with other sports for which there were values.

Food intake. The amounts of all food and beverages consumed each day during the study were recorded in a diary-type booklet by each subject. Quantities were recorded in oz, or by volume for liquids, or in terms of household measures. 
The daily intake of calories and nutrients of each subject was calculated from tables of food composition. The Tables of Composition of Australian Foods (Osmond \& Wilson, I96I) were used as the source of figures for the composition of the majority of foodstuffs, supplemented by information on manufactured and home-cooked products provided by other publications (Bourne, 1938; Watt \& Merrill, 1950; Woodhill, I952; Wilson, I957; McCance \& Widdowson, 1960). In the calculations allowances were made for losses of thiamine and ascorbic acid during the cooking of certain foodstuffs. A reduction of $50 \%$ was made in the thiamine content of cooked

\section{Table 2. Values used to estimate the energy cost of various activities} expressed as kcal/min

\section{Activity}

Sleeping, lying in bed Sitting

Standing

Typing

Stenographer, comptometrist

Laboratory work

Walking

Selling merchandise

Dressing and personal necessities

Household tasks, general

Cooking

Ironing

Laundry, washing dishes

Sweeping

Making beds

Polishing floors

Gardening

Chopping wood

Riding a bicycle

Running
Tennis
Squash
Cricket
Swimming

Golf
Dancing
Rowing
Physical exercises
Horse-riding
Football
Hockey

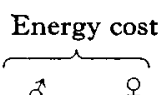

o 0

See p. 333

I. $6 \quad I \cdot I$
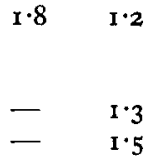

- $\quad \mathrm{r} .8$

see p. 333

(2.5) $(2 \cdot 0)$

$4.0 \quad 3.0$

$4.5 \quad 3.5$

- 2.5

$4.2 \quad 2.5$

$3.5 \quad 3.0$

- $\quad 3.0$

- 45

- 5.0

$7 \cdot 0$

$8 \cdot 0$

6.0

5.0

6.0

$9.0 \quad 9.0$

$7 \cdot 0 \quad(5 \cdot 0)$

$7.0 \quad(5.0)$
$10.0 \quad-$

$\begin{array}{rr}5.0 & - \\ 10.0 & 10.0\end{array}$

$5 \cdot 0 \quad(5 \cdot 0)$

$5.0 \quad 6.0$

$6.0-$

$4.0-$

$5 \cdot 0$
$(7.0)$

$(7.0)-$
Literature studied

Robertson \& Reid (1952),

Edholm et al. (1955), Garry et al. (I955), Durnin et al. (1957), Richardson \& McCracken (1960)

Edholm et al. (1955), Garry et al. (1955), Durnin et al. (1957), Elliot et al. (1963)

Marro et al. (1954)

See p. 337

See p. 337

McDonald (196I)

See p. 337, value based on records of physical activity

Passmore et al. (1952), Edholm et al. (I955), Kraut et al. (1956)

See p. 333

Garry et al. (1955), Edholm et al. (1955), Passmore \& Durnin (r955), Kraut et al. (1956), Durnin et al. (1957), Maksimov (196r), Elliot et al. (1963), Hoopes \& Patton (r963)

Passmore \& Durnin (1955), Edholm et al. (1955), Garry et al. (1955), Grimsby \& Söderholm (I962) Ogasawara (1934), Margaria et al. (1963)

Edholm et al. (1955)

Edholm et al. (1955)

Edholm et al. (1955)

Karpovich \& Millman, (1944),

Pugh \& Edholm (1955), Pugh et al. (1960)

Garry et al. (1955)

Passmore et al. (1952)

Passmore \& Durnin (1955)

Edholm et al. (1955), Passmore \&

Durnin (r955)

Geldrich (1927)

Assigned value

Assigned value 
meat, $25 \%$ in the thiamine content of cooked vegetables, and $50 \%$ in the ascorbic acid content of cooked fruits and vegetables.

Vitamin A activity was calculated by the method suggested by the National Health and Medical Research Council: Australia (1965). The nicotinic acid content of the diet was expressed in nicotinic acid equivalents, as suggested by Horwitt, Harvey, Rothwell, Cutler \& Haffron (1956).

\section{RESULTS}

Although the children attending schools $\mathrm{I}$ and 2 were on the whole from families of a higher socio-economic level than the families of the children attending school 3 , the means for size, physical activity and food intake were almost identical for the similar ages and sexes. Therefore the results have been pooled.

Age, height and initial weight. The group means are given in Table 3 .

Table 3. Age, height and initial weight of subjects taking part in the study

(Mean values and standard deviations)

\begin{tabular}{|c|c|c|c|c|}
\hline Subjects & No. & $\begin{array}{l}\text { Mean age } \\
\text { (years) }\end{array}$ & $\begin{array}{l}\text { Mean height } \\
\text { (cm) }\end{array}$ & $\begin{array}{c}\text { Mean weight } \\
(\mathrm{kg})\end{array}$ \\
\hline \multicolumn{5}{|c|}{ Boys } \\
\hline \multicolumn{5}{|l|}{ 16-I 7 years } \\
\hline Schoolboys & 62 & $16.95 \pm 0.56$ & $177^{\circ} \circ \pm 7^{\circ} 04^{a}$ & $69 \cdot 6 \pm 9 \cdot 55^{d}$ \\
\hline Employed boys & 9 & $16.7 \pm 0.51$ & $172 \cdot 7 \pm 9 \cdot 80$ & $65 \cdot 0 \pm 9 \cdot 56$ \\
\hline \multicolumn{5}{|l|}{$18-19$ years } \\
\hline Schoolboys & 12 & $18 \cdot 1 \pm 0 \cdot 15$ & $179 \pm 3 \cdot 34$ & $73 \cdot 2 \pm 8 \cdot 13$ \\
\hline Employed boys & 9 & $18.6 \pm 0.44$ & $176 \cdot 27 \pm 6 \cdot 96$ & $68 \cdot 4 \pm 8 \cdot 44^{e}$ \\
\hline \multicolumn{5}{|c|}{ Girls } \\
\hline \multicolumn{5}{|l|}{$16-17$ years } \\
\hline Schoolgirls & I I 3 & $16.6 \pm 0.53$ & $163 \cdot 6 \pm 5 \cdot 13^{b}$ & $58 \cdot 3 \pm 5 \cdot 44^{f}$ \\
\hline Employed girls & 32 & $16.6 \pm 0.59$ & $161 \cdot 3 \pm 5 \cdot 54^{c}$ & $54 \cdot 75 \pm 7 \cdot 21^{g}$ \\
\hline \multicolumn{5}{|l|}{$18-19$ years } \\
\hline Schoolgirls & 4 & $18 \cdot 1 \pm 0.25$ & $165 \cdot 3 \pm 9 \cdot 19$ & $62 \cdot 4 \pm 5 \cdot 45$ \\
\hline Trainee teachers & 15 & $19.0 \pm 0.76$ & $162 \cdot 6 \pm 6 \cdot 14$ & $57 \cdot 2 \pm 4 \cdot 56^{h}$ \\
\hline Employed girls & 22 & $18.7 \pm 0.44$ & $16 I \cdot 0 \pm 5^{\circ} 5^{1}$ & $54.75 \pm 5.62$ \\
\hline
\end{tabular}
(a) Mean height of $6 \mathrm{I}$ subjects.
(b) Mean height of 1 I 2 subjects.
(c) Mean height of 31 subjects.
(e) Mean weight of 8 subjects.
(f) Mean weight of 1 Io subjects.
(d) Mean weight of 59 subjects.
(g) Mean weight of $3 \circ$ subjects.
(h) Mean weight of 13 subjects.

Final weight. One hundred and eleven of the 245 subjects whose weights were recorded again at the end of the 7 days showed no change in weight, seventy-two had gained weight and sixty-two had lost weight.

Physical activity. The group means for the amount of time spent performing each of the activities carried out during each 7 -day period are shown in Table 4 . The amount of time any one subject spent performing the same activity on different days often varied widely. The average amount of time different subjects spent on the same activity also varied widely.

All the boys in the study either took part in sport, or performed some kind of manual labour. Only one boy in each age-group spent less than $85 \mathrm{~min}$ in one or other of 


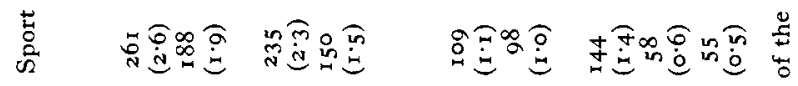

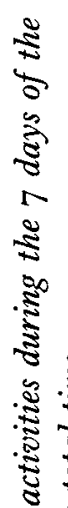

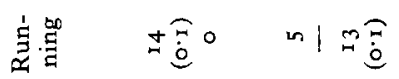

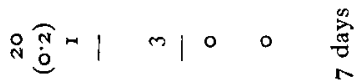

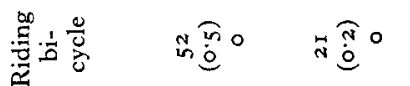

它员

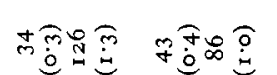

$+10000 \%$

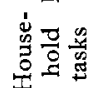

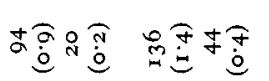

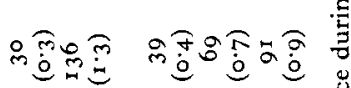

耪

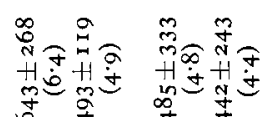

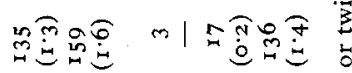

齐

离.

苞 $\therefore 1000$

药

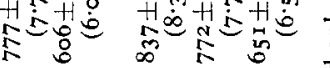

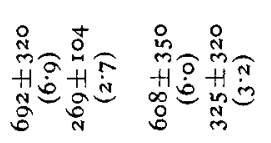

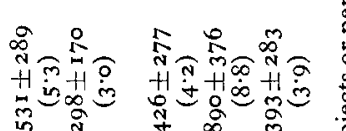

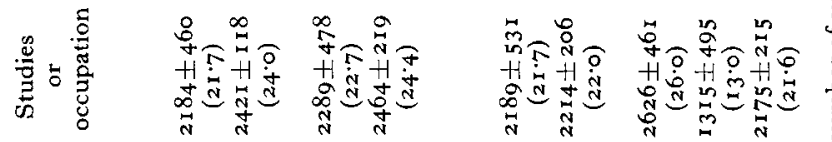

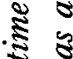

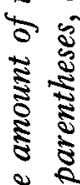

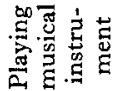

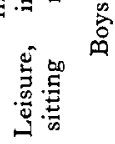

寅

$\infty 1^{\circ} \circ$ 。

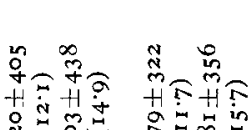

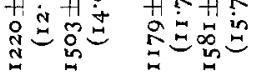

+每。

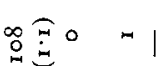

$\sum_{0}^{\infty}$

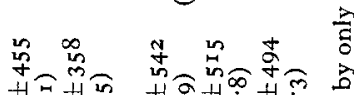

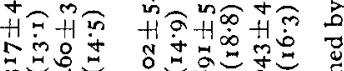

$\lesssim$

离

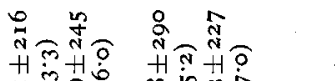

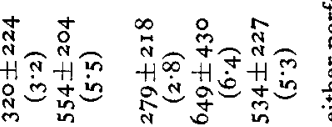

莺

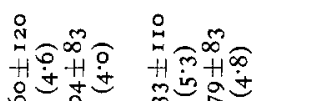

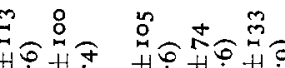

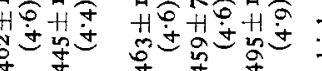

है

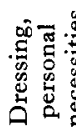

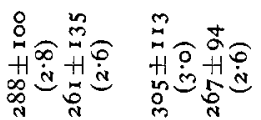

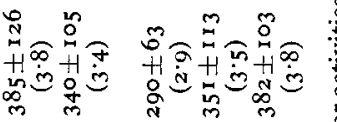

है

$\stackrel{\mathscr{E}}{\mathrm{E}}: \Xi$

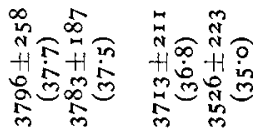

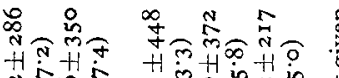

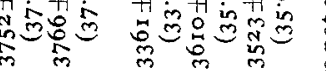

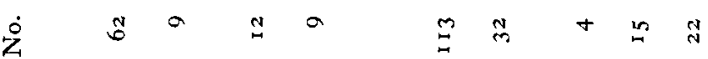

齐

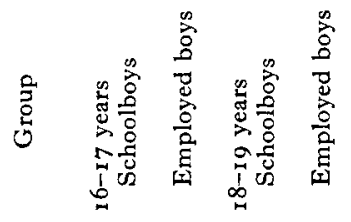

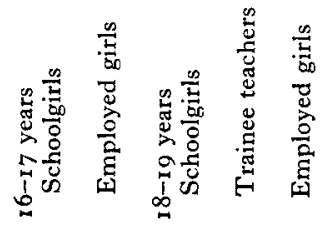


these activities during the 7-day period. On the other hand, seven girls in the $16-17$ years age-group and six girls in the $18-19$ age-group did not undertake any active pursuits during the study, and seven others spent less than $35 \mathrm{~min}$ in such activities.

Twenty-nine $(40.8 \%)$ of the boys aged $16-17$ and nine $(42 \cdot 9 \%)$ of those aged I8-19 reported doing manual labour, and seventy-five $(5 \mathrm{I} \cdot 7 \%)$ of the girls aged $\mathrm{I} 6-\mathrm{I} 7$ and thirteen $(3 \mathrm{I} \cdot 7 \%)$ of the girls aged $18-19$ did housework or some similar task during the week.

Table 5. Group means and standard deviations for estimated daily energy expenditure

$\begin{array}{lccc}\text { Group } & \begin{array}{c}\text { Age } \\ \text { (years) }\end{array} & \text { No. } & \begin{array}{c}\text { Energy expenditure } \\ \text { (kcal) }\end{array} \\ \text { Schoolboys } & 16-17 & 62 & 2776 \pm 247 \\ \text { Employed boys } & 16-17 & 9 & 2886 \pm 235 \\ \text { Schoolboys } & 18-19 & 12 & 2714 \pm 276 \\ \text { Employed boys } & 18-19 & 9 & 2740 \pm 268 \\ \text { Schoolgirls } & 16-17 & 113 & 2025 \pm 167 \\ \text { Employed girls } & 16-17 & 32 & 2139 \pm 237 \\ \text { Schoolgirls } & 18-19 & 4 & 2043 \pm 189 \\ \text { Trainee teachers } & 18-19 & 15 & 1904 \pm 143 \\ \text { Employed girls } & 18-19 & 22 & 2069 \pm 159\end{array}$

Although many of the employed subjects found it difficult to record their activities in detail while they were at work, several subjects in each category kept detailed records of their allocation of time during working hours. These results were used as a basis for the development of a value for average energy expenditure per min for the various employment classifications. Typists and comptometrists were estimated to spend $40 \%$ of their time sitting typing or using a calculating machine, $40 \%$ sitting doing other tasks, $15 \%$ walking and $5 \%$ standing and filing records. Female laboratory workers were estimated to spend, on the average, $30 \%$ of their time walking, $10 \%$ sitting and $60 \%$ standing and working at the laboratory bench.

Energy expenditure. The group means for the calculated daily energy expenditure are given in Table 5 .

Food intake. In general, the eating habits of the subjects conformed to the typical Australian pattern. The majority had three meals daily and also consumed food and beverages between these meals.

Seventy-three subjects (twenty-three boys and fifty girls) omitted at least one meal during the study. This number included fifteen male students $(20.3 \%$ of the total number of male students), twenty-six female students ( $19 \cdot 7 \%$ ), eight employed male subjects $(44 \cdot 4 \%)$, and twenty-four female employed subjects $(44 \cdot 4 \%)$.

On the whole the schoolchildren had a more stable pattern of food intake from day to day than the other subjects. There were no significant differences between the patterns of food intake of the children attending the independent schools and those attending the State-run secondary school. The least satisfactory pattern of intake was that of the employed girls. Their intake of milk, eggs, and vegetables other than potatoes was much smaller than that of the female students. The differences in the 


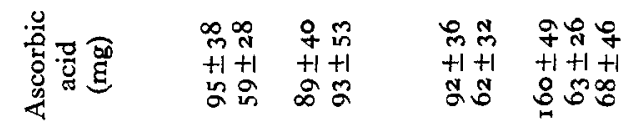

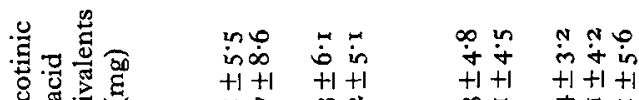

乙.

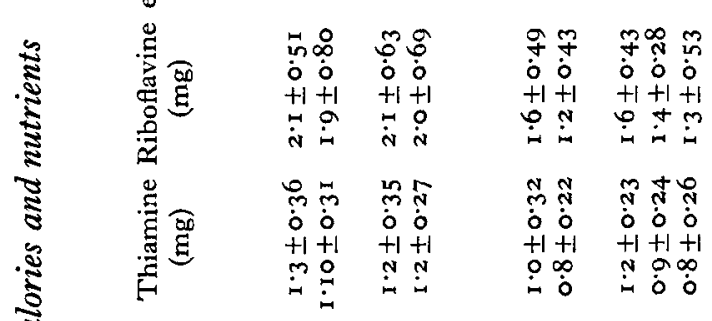

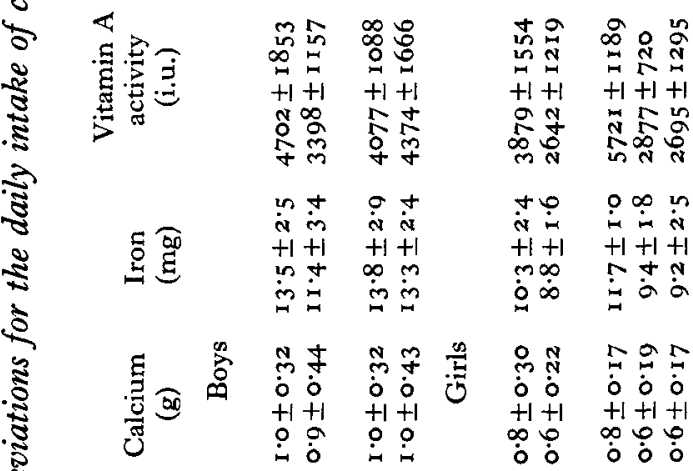

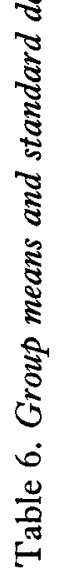

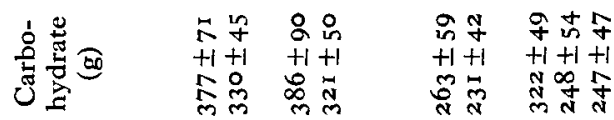

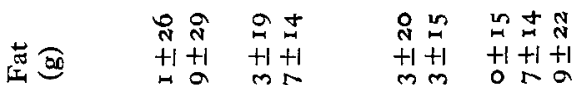

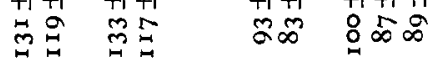

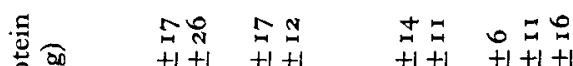

造 $+1+1+1+1+1+1+1+1$

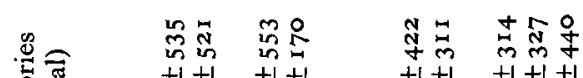

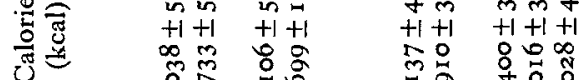

贷令

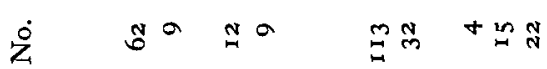

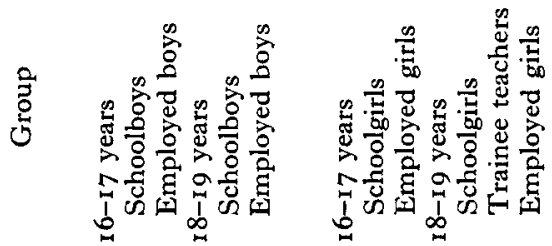


Vol. 24

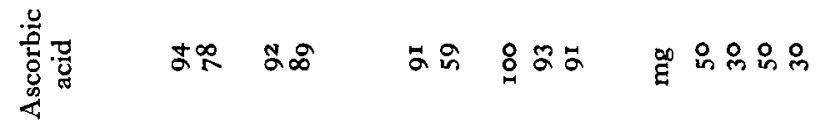

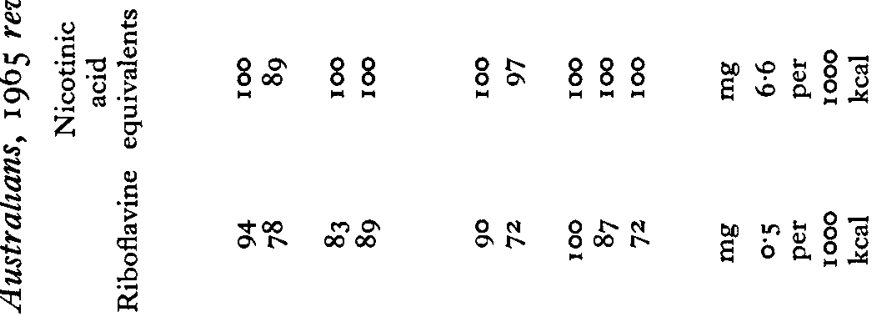

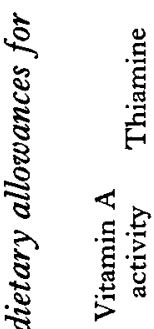

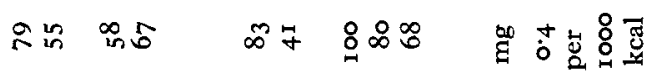

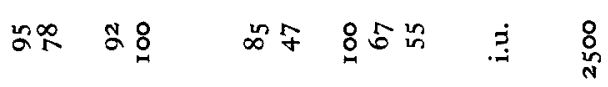

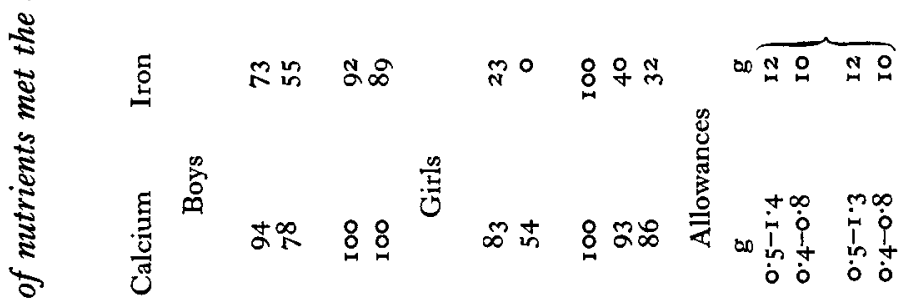

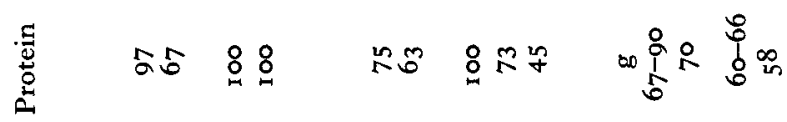

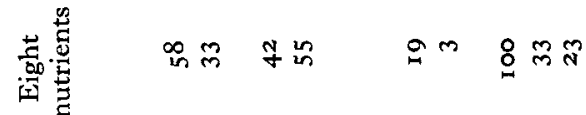

ही

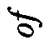

吾

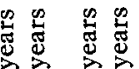

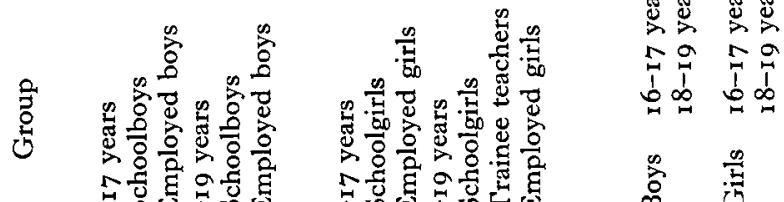

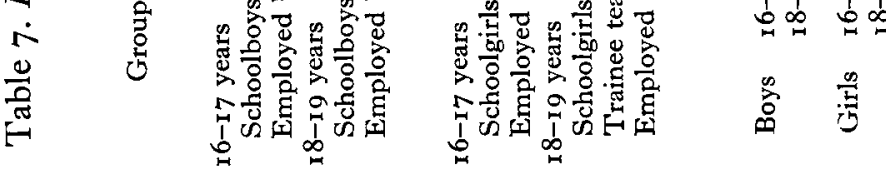



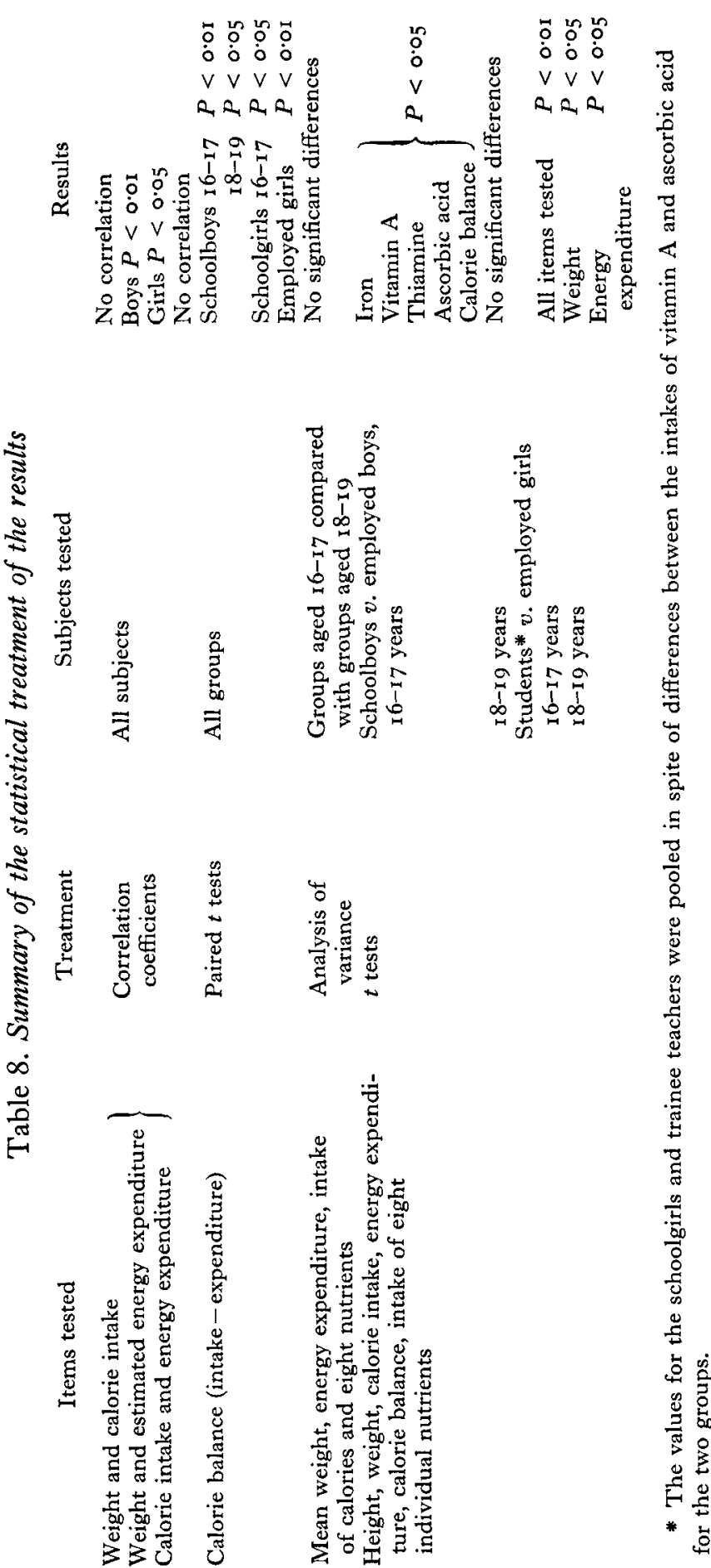
overall pattern of intake of the employed girls compared with that of the students were not great, but the trend was always such that meal patterns tended to be less satisfactory than those of the students.

Intake of calories and nutrients. The group means for the daily intake of calories and nutrients are given in Table 6.

The relative contribution made to the calorie intake by protein, fat and carbohydrate was similar for all groups. Between $\mathrm{I} 2$ and $\mathrm{I} 3 \%$ of calories was derived from protein, between 38 and $39 \%$ from fat, and approximately $49 \%$ from carbohydrate.

Observed intakes and dietary allowances for Australians, 1965 revision. Although our results were available to the Nutrition Committee of the National Health and Medical Research Council when the Dietary Allowances for Australians (National Health and Medical Research Council: Australia, 1961) were being revised in 1965, and were taken into consideration in establishing the allowances of calories and iron for the I 5-I 8 year age-group, it may be of some interest to review our findings in relation to the revised allowances (National Health and Medical Research Council: Australia, 1965). The percentage of subjects whose mean daily nutrient intakes met the dietary allowances is shown in Table 7 .

Statistical treatment of the results. The results were treated statistically by standard methods (Bailey, I959) to determine if the various differences observed were significant (see Table 8).

\section{DISCUSSION}

\section{Height, weight and calorie intake}

The only Australian data on individuals in the same groups as the subjects of the present study are those of Wardlaw \& White (1940). These investigators did not compute the mineral or vitamin content of the diets consumed by the schoolboys they studied, and the only information they give with regard to energy expenditure is that their subjects 'led the normal active life of schoolboys in this country'.

The mean calorie intake for their subjects was less than that of the schoolboys in the present study. Their average heights and weights were also lower. Although the number of subjects studied by Wardlaw $\&$ White was much smaller than the number in our study, and therefore interpretation of differences in the results of the two studies is difficult, it appears that an increase in the heights and weights of adolescents similar to that observed in Britain (Leitch \& Boyne, I960) may have taken place in Australia in the past 20 years.

The subjects in the present study were considerably heavier than the Australian standards for weight for children of the same age (Australian Institute of Anatomy, I957).

\section{Adequacy of the dietary intake}

Few subjects had consistently unsatisfactory patterns of food intake, but there was sometimes considerable variation in the quantity of food consumed by an individual from one day to another. In general the mean daily intakes of protein, calcium, vitamin A, thiamine, riboflavine, nicotinic acid and ascorbic acid appeared satisfactory. The observed iron intakes of the female subjects, particularly those of the 
employed girls aged $16-17$, were below the levels usually considered desirable (National Health and Medical Research Council: Australia, 1965). No biochemical tests or clinical examinations were carried out on the subjects enrolled in this study, and therefore there is no evidence of the existence or otherwise of an iron-deficiency anaemia among the girls.

The differences between the pattern of food intake of the students and the employed subjects have been mentioned already.

Income and educational level are two factors that have been shown to affect the dietary patterns of households and individuals.

In our study some of the employed subjects had family backgrounds similar to those of the children who attended the independent schools; more came from families resembling those of the subjects who attended the State-run secondary school. We do not know the reasons for the difference between the patterns of food intake of the two groups. Social factors certainly contributed. One reason for the difference was probably the relaxation of, or their refusal to accept, parental control over their eating habits once they became wage-earners; another was the clash between other activities and meal-times.

Relationship between energy expenditure and calorie intake. It has been established that there is considerable individual variation in the energy cost of ordinary every day activities (Mahadeva, Passmore \& Woolf, I953; Durnin \& Weir, I954; Booyens \& McCance, I957; Durnin \& Namyslowski, 1958). In order to obtain accurate information on the energy expenditure of an individual, actual measurements of his oxygen consumption must be made during each of the various activities he engages in during the course of a day. However, Orr \& Leitch (1938) and Passmore \& Durnin (1955) have suggested that the energy expenditure of groups of individuals can be estimated with a reasonable degree of accuracy using published data on the energy cost of specific activities, provided the amount of time spent on these different activities is known. This approach was adopted in this study. It is realized that the methods used to estimate energy expenditure and to calculate the intake of calories can only give approximate results. Durnin (1957) and Durnin \& Brockway (1959) discuss the possible source of error in experiments of this type and point out that differences of $20-30 \%$ occur between the estimated calorie intake and energy expenditure of an individual on any one day. In general our subjects were sedentary and spent a very small proportion of their time in any physical activity more strenuous than walking. As pointed out earlier, our sample was biased in that it did not contain any subjects whose occupation entailed prolonged physical exertion.

Although there are no other published data on the activity of older Australian children, our findings are similar to those reported for American schoolchildren by Huenemann et al. (1967). Both the English children studied by Bedale (1922-3) and the Russian schoolboys studied by Borisov (1961) were more active than the schoolchildren in our sample.

Even when allowance is made for errors in the estimation of energy expenditure and calorie intake in this study, the mean calorie intakes of the students appear adequate to meet energy requirements and to supply any additional calories needed for growth. 
With the exception of the employed girls aged I6-I 7 , the employed subjects appear to have been in approximate calorie balance over the 7 days of the investigation.

The highly significant negative calorie balance of the employed girls aged $16-17$ calls for comment. The difference between intake and expenditure may have been due in part to an overestimate of the energy expenditure while working, and in part to the under-recording of their food intake by these subjects. On the other hand, there is no reason why this should have been so for the employed girls aged $16-17$, but not for the employed girls aged 18-19.

It is obvious that a group cannot remain in a state of negative calorie balance over a period of time without losing weight. The changes of weight observed in the employed girls during the 7 days did not appear to bear any relation to the calorie balance of the individual subjects. This was also true for the group as a whole. Not all subjects whose calorie intake exceeded their energy expenditure gained weight. Similarly, not all subjects who showed a negative calorie balance over the 7 days lost weight. Other workers have pointed out that changes in weight over short periods are just as likely to be related to changes in water balance as to calorie balance (Edholm, 196r; Taggart, I962).

The information obtained in the present study confirms the observations of others concerning individual variations in energy expenditure and calorie intake, and the lack of correlation between energy expenditure, calorie intake and changes in the bodyweight of individuals over short periods (Durnin, 1957; Harries, Hobson \& Hollingsworth, 1962). Subjects who expended more energy did not necessarily eat more than subjects who were less active. Subjects who consumed more food did not necessarily weigh more than their fellows.

Our findings indicate that, for the subjects examined in this study, calorie balance is not achieved over a period of a few days. Of interest is the finding that there were significant differences between the calorie intakes and energy expenditures of the schoolboys at both ages and for both schoolgirls and employed girls in the $16-17$ year age-group. The direction of this and other differences between the schoolgirls and employed girls in the 16-17 year age-group suggests the need for further studies on the nutritional status of employed girls in this age group.

We wish to thank Dr G. H. Howett and Miss Betty Laby, Statistics Department, University of Melbourne, for carrying out the statistical analyses of the results.

This work was supported by a Research Grant from the University of Melbourne.

\section{REFERENCES}

Australian Institute of Anatomy (1957). Standard Height-Weight Tables for Australians. Canberra: Government Printer.

Bailey, N. T. J. (1959). Statistical Methods in Biology. London: The Universities Press Ltd.

Bedale, E. M. (1922-3). Proc. Roy. Soc. Lond. B 94, 368.

Booyens, J. \& McCance, R. A. (1957). Lancet i, 225.

Borisov, A. P. (1961). Vop. Pitan. 20, 21.

Bourne, G. (1938). In Fifth Report of the Advisory Committee on Nutrition, Commonwealth of Australia, Appendix 1. Canberra: Government Printer. 
Consolazio, C. F., Johnson, R. E. \& Marek, E. (195I). Metabolic Methods. St Louis: The_C. V. Mosby Co.

Durnin, J. V. G. A. (1957). F. Physiol., Lond. 136, $34 P$.

Durnin, J. V. G. A., Blake, E. C. \& Brockway, J. M. (1957). Br. F. Nutr. 1r, 85.

Durnin, J. V. G. A. \& Brockway, J. M. (1959). Br. F. Nutr. 13, 4I.

Durnin, J. V. G. A. \& Namyslowski, L. (1958). F. Physiol., Lond. 143, 573.

Durnin, J. V. G. A. \& Weir, J. B. de V. (1954). F. Physial., Lond. 125, $60 P$.

Edholm, O. G. (196I). Proc. Nutr. Soc. 20, 7 I.

Edholm, O. G., Fletcher, J. G., Widdowson, E. M. \& McCance, R. A. (1955). Br. Y. Nutr. 9, 286.

Elliot, D. E., Patton, M. B. and Singer, M. E. (1963). Res. Bull. Ohio agric. Exp. Stn no. 939.

Garry, R. C., Passmore, R., Warnock, G. M. \& Durnin, J. V. G. A. (1955). Spec. Rep. Ser. med. Res. Coun. no. 289.

Geldrich, J. (1927). Biochem. Z. 183, I.

Grimsby, C. \& Söderholm, B. (1962). Scand. F. clin. Lab. Invest. 14, 321.

Harries, J. M., Hobson, E. A. \& Hollingsworth, D. F. (1962), Proc. Nutr. Soc. $21,157$.

Hoopes, J. R. \& Patton, M. B. (I963). Res. Bull. Ohio agric. Exp. Stn no. 946.

Horwitt, M. K., Harvey, C. C., Rothwell, W. S., Cutler, J. L. \& Haffron, D. (1956). F. Nutr. 6o, Suppl. I.

Huenemann, R. L., Shapiro, L. R., Hampton, M. C. \& Mitchell, B. W. (1967). F. Am. diet. Ass. 5r, 433.

Karpovich, P. V. \& Millmann, N. (1944). Am. F. Physiol. 142, I40.

Kraut, H., Schneiderholn, R. \& Wildemann, L. (1956). Int. Z. angew. Physiol. 16, 275.

Leitch, I. \& Boyne, A. W. (1960). Nutr. Abstr. Rev. 30, 1173.

McCance, R. A. \& Widdowson, E. M. (I960). Spec. Rep. Ser. med. Res. Coun. no. 297.

McDonald, I. (196r). Nutr. Abstr. Rev. 31, 739.

Mahadeva, K., Passmore, R. \& Woolf, B. (1953). J. Physiol., Lond. 121, 225.

Maksimov, V. V. (196r). Gig. Sanit. 26, 33 .

Margaria, R., Cerretelli, P., Aghemo, P. \& Sassi, G. (1963). F. appl. Physiol. 18, 367.

Marro, F., Milani, B. \& Vigliani, E. C. (1964). Med. d. Lavoro 45, I2.

National Health and Medical Research Council: Australia (196r). Med. F. Aust. 2, I052.

National Health and Medical Research Council: Australia (1965). Dietary Allowances for AustraliansI965 Revision. Reprinted from Report of 6oth Session, October 1965. Canberra: Government Printer.

Ogasawara, M. (1934). F. Physiol., Lond. 81, 255.

Orr, J. B. \& Leitch, I. (1938). Nutr. Abstr. Rev. 7, 509.

Osmond, A. \& Wilson, W. (196r). Tables of Composition of Australian Foods. Canberra: Government Printer.

Passmore, R. \& Durnin, J. V. G. A. (1955). Physiol. Rev. 35, 801.

Passmore, R., Thomson, J. G. \& Warnock, G. M. (1952). Br. Y. Nutr. 6, 253.

Pugh, L. G. C. \& Edholm, O. G. (1955). Lancet ii, 76r.

Pugh, L. G. C., Edholm, O. G., Fox, R. H., Wolff, H. S., Hervey, G. R., Hammond, W. H., Tanner, J. M. \& Whitehouse, R. H. (1 960). Clin. Sci. 19, 257.

Richardson, M. \& McCracken, E. C. (1960). Home Econ. Res. Rep. U.S. Dep. Agric. no, II.

Robertson, J. D. \& Reid, D. D. (1952). Lancet. i, 940.

Taggart, N. (1962). Br. F. Nutr. 16, 223.

Wardlaw, H. S. H. \& White, C. J. (1940). Aust. F. exp. Biol. med. Sci. r8, 9.

Watt, B. K. \& Merrill, A. L. (I950). Agric. Hdbk U.S. Dep. Agric. no. 8.

Wiehl, D. G. (1944). Milbank meml Fund q. Bull. 22, 5.

Wilson, W. (1957). Simplified Food Composition Tables. Canberra: Government Printer.

Woodhill, J. (1952). Med. F. Aust. ii, 188. 